J. Clin. Chem. Clin. Biochem.

Vol. 14, 1976,pp. 421-427

\title{
A New Method for the Determination of $\boldsymbol{\gamma}$-Glutamyltransferase in Serum
}

By J. P. Persijn and W. van der Slik

From the Department of Clinical Chemistry (Head Dr. J. P. Persijn), Antoni van Leeuwenhoekziekenhuis, Amsterdam, and the Central Laboratory of Clinical Chemistry (Head Dr. W. van der Slik), State University, Leiden, The Netherlands

(Received February 18/March 29, 1976)

Summary: A new, simple and sensitive method is described for assay of serum $\gamma$-glutamyltransferase activity based on the hydrolysis of the substrate $L-\gamma$-glutamyl-3-carboxy-4-nitranilide which offers the advantage of producing directly its own chromogen.

The substrate is highly soluble and the method can therefore easily be adapted to any equipment for the automated assay of $\gamma$-glutamyltransferase.

The activities at measured optimum substrate concentration are slightly higher than with the Szasz ((1969), Clin. Chem. 15, 124-136) method in which $L$-glutamyl-p-nitroanilide is used as substrate.

\section{Eine neue Methode zur Bestimmung der $\gamma$-Glutamyltransferase im Serum}

Zusammenfassung: Es wird eine einfache und empfindliche neue Methode für die Bestimmung der $\gamma$-Glutamyltransferase-Aktivität im Serum beschrieben. Sie beruht auf der Hydrolyse des Substrats $L$ - $\gamma$-Glutamyl-3-carboxy-4-nitranilid.

Die Freisetzung von 3-Carboxy-4-nitroanilin wird kontinuierlich bei $405 \mathrm{~nm}$ gemessen.

Das Substrat ist sẹr gut löslich. Die Methode kạnn daher vorzüglich auf alle automatischen Annalysen-Geräte adaptiert werden.

Bei Messung im Substrat-Optimum ergibt die neue Methode etwas (1,22fache) höhere Werte als die bisher generell verwendete Bestimmung der $\gamma$-Glutamyltransferase nach Szasz ((1969), Clin. Chem. 15, 124-136) mit $L$-Glutamyl- . $p$-nitranilid als Substrat. Die Korrelationskoeffizient beider Methoden betrug $\mathrm{r}=0.999$.

\section{Introduction}

In measuring serum $\gamma$-glutamyltransferase (EC 2.3.2.2) activity, the natural substrate glutathione was initially used (1). During the Sixties the synthetic substratés $D, L-\gamma$-glutamylaminoproprionitril (2), $\mathrm{N}-(D, L-\gamma-$ glutamyl)aniline (3), $L$ - $\gamma$-glutamyl- $\alpha$-naphthylamide (4) and $L$ - $\gamma$-glutamyl-p-nitranilide (5) were proposed. Only the last-mentioned of these substrates has been retained for routine use, for the following reasons:

1. No additional monitoring reaction is required to produce a dye, as is the case with the cleavage products of the other substrates.

2. The molar absorptivity is sufficient $\left(9.9 \mathrm{~cm}^{2} / \mu \mathrm{mol}\right.$ at $405 \mathrm{~nm}$ ) for adequately exact measurement of the transition range between normal and pathological.
3. A kinetic method has been described to study, in greater deal than for the other substrates, various factors which influence $\gamma$-glutamyltransferase (6).

4. Most of the more elaborate studies which have established the value of $\gamma$-glutamyltransferase assays in the diagnosis and therapeutic management of hepatobiliary disease, were performed with this substrate (7-16). The use of $L-\gamma$-glutamyl- $p$-nitranilide poses practical problems due to its poor solubility. In order to obtain a substrate concentration which is close to optimal, dissolution under heat application is required (which, however, promotes autolysis of the substrate); a possible alternative is dissolution in an acid medium followed by alkalization.

Due to low solubility, $L$ - $\gamma$-glutamyl-p-nitranilide cannot be used with equipment which measures $\gamma$-glutamyl- 
transferase kinetically and starts the reaction by the addition of a small volume of substrate solution.

These considerations prompted us to search for better substrates. We first tested a few dipeptides but, because the indicator reaction took an unfavourable course, we switched to new synthetic substrates derived from $L$ - $\gamma$-glutamyl-p-nitranilide, by derivatization of the $p$-nitraniline moiety. Two of these ( $L$ - $\gamma$-glutamyl-3. carboxy-4-nitranilide and $L-\gamma$-glutamyl-3-sulphonic-4nitranilide) proved to be very good substrates for $\boldsymbol{\gamma}$-glutamyltransferase with high turnover rates and more than 50 times the solubility of $L-\gamma$-glutamyl- $p$-nitranilide, and thus could be accepted as alternatives. Preliminary communications announcing the applicability of these substrates have already appeared $(17,18)$. In our study we established optimal conditions with these substrates, and this paper describes a kinetic method using $L-\gamma$ glutamyl-3-carboxy-4-nitranilide.

\section{Materials and Methods}

The substrates $L$ - $\gamma$-glutamyl-3-carboxy-4-nitranilide (Molecular weight 345 ) and $L$ - $\gamma$-glutamyl-3-sulphonic-4-nitranilide (Molecular weight 382 ) and other derivatives from $L$ - $\gamma$-glutamyl-p-nitranilide, were synthesized by the Boehringer Mannheim Company, Tutzing, Germany.

\section{Reagent}

(buffered substrate solution)

Dissolve $12.917 \mathrm{~g}$ (106.7 mmol/1) Tris (hydroxymethyl) aminomethane and $21.136 \mathrm{~g}(160.0 \mathrm{mmol} / \mathrm{l})$ glycylglycine (Fluka) in $900 \mathrm{ml}$ bidistilled water. Adjust the $\mathrm{pH}$ to 8.2 at $25^{\circ} \mathrm{C}$. Add $2.208 \mathrm{~g}(6.4 \mathrm{mmol} / \mathrm{l}) L$ - $\gamma$-glutamyl-3-carboxy-4-nitranilide (ammonium salt with 1 mol $\mathrm{H}_{2} \mathrm{O}$ ). The volume is made up to $1000 \mathrm{ml}$ with bidistilled water and is checked again to be 8.2 .

The absorbance of the freshly prepared solution increases about $7 \%$ within 24 hours when stored at room temperature (this corresponds to less than $1.0 \mathrm{U} / 1)$.

Procedure

Serum $(0.2 \mathrm{ml})$ is added to buffered substrate $(3.0 \mathrm{ml})$ equilibrated to $25^{\circ} \mathrm{C}$. The increase of absorbance at $405 \mathrm{~nm}$ in $1.0 \mathrm{~cm}$ light path is recorded during 10 minutes immediately after mixing.

Calculation of activity

Activity $(\mathrm{U} / \mathrm{l})=\Delta \mathrm{A} / \mathrm{min} \times 1690$

The factor $1690=\frac{3.2 \times 1000}{0.2 \times 9.49}$ is derived from:

3.2: total volume [ml]

1000: conversion to $U / 1$

0.2: $\quad$ sample volume [ml]

9.49: molar absorptivity $\left[\mathrm{cm}^{2} / \mu \mathrm{mol}\right]$ of 2 nitro-5aminobenzoate

For calculation of activity it should be taken into account that the increase of absorbance per minute at $405 \mathrm{~nm}(\Delta \mathrm{A} / \mathrm{min})$ is not linear with time after 5 minutes reaction time for activities higher than $200 \mathrm{U} / 1$. Below $150 \mathrm{U} / 1$ the rate of the reaction is linear during the first 10 minutes.

\section{Apparatus}

Measurements were performed with the Zeiss PMQ II equipped with an automatic slit control and T/A converter. The position of the automatic slit control was taken by a cuvette filled with buffered substrate.

\section{Results}

\section{Preliminary experiments with dipeptides}

Hanes et al. described $L$ - $\gamma$-glutamyl- $L$-glutamic acid as substrate for $\boldsymbol{\gamma}$-glutamyltransferase (1). Our expectation was that the resulting glutamic acid could be simultaneously converted to ammonia by addition of the auxiliary enzyme glutamate dehydrogenase. The NADH formed in this reaction could be used to measure the $\gamma$-glutamyltransferase by continuous monitoring of the reaction at $340 \mathrm{~nm}$. Leucine, added as acceptor (1) could act as stabilizer for glutamate dehydrogenase, as suggested by Persijn et al. (19). Unfortunately, the indicator reaction was rate-limiting; this was also the case with the alternative substrate $L$ - $\gamma$-glutamyl- $D$-alanine. Here, the plan was to couple the liberation of $D$-alanine to its deamination by $D$-amino acid oxidase, followed by reduction by lactate dehydrogenase in the presence of NADH.

Preliminary experiments with substrates derived from $L$ - $\gamma$-glutam yl-p-nitranilide

A number of substrates derived from $L$ - $\gamma$-glutamyl-pnitranilide by introduction of hydrophilic groups or alteration of the benzene ring were tested for solubility and suitability as substrate for measuring $\gamma$-glutamyltransferase. The results of these tests are presented in table 1. Relative activities were determined without accounting for possible differences in optimal concentration between the various subștrates.

The results encouraged us to continue the study with the compounds that have a carboxyl or sulphonyl group on the 3 position. The favourable spectral properties of both substrates and their cleavage products were an additional argument for further investigation. The shape of the spectrum of the cleavage products of $L$ - $\gamma$-glutamyl$p$-nitranilide, $L$ - $\gamma$-glutamyl-3-carboxy-4-nitranilide, and $L$ - $\gamma$-glutamyl-3-sulphonic-4-nitranilide is the same. However, the 2-nitro-5-amino-benzenesulphonic acid shows a significantly lower absorbance at $405 \mathrm{~nm}$ than the other two compounds. The molar absorptivities of 2-nitro-5aminobenzoic acid and 2-nitro-5-aminobenzenesulphonic acid at $405 \mathrm{~nm}$ are 9.49 and $5.45 \mathrm{~cm}^{2} / \mu \mathrm{mol}$, respectively. These values were independent of the $\mathrm{pH}$ in range 7-9. The substrates $L$ - $\gamma$-glutamyl-3-carboxy-4-nitranilide and $L$ - $\gamma$-glutamyl-3-sulphonic-4-nitranilide show no measurable absorbance at wavelengths higher than $410 \mathrm{~nm}$. The absorption maxima of these $L$ - $\gamma$-glutamyl- $p$ nitranilide derivatives in Tris buffer are $317 \mathrm{~nm}$ (molar absorptivity: $11.7 \mathrm{~cm}^{2} / \mu \mathrm{mol}$ ) and $290 \mathrm{~nm}$ (molar absorp- 

Tab. 1. Solubilities and relative activities at a concentration of $4 \mathrm{mmol} / 1$ of various derivatives of $L-\gamma$-glutamyl-p-nitranilide in Tris
buffer ( $200 \mathrm{mmol} / \mathrm{l}, \mathrm{pH} 8.2)$ containing glycylglycine $(40 \mathrm{mmol} / \mathrm{l})$.

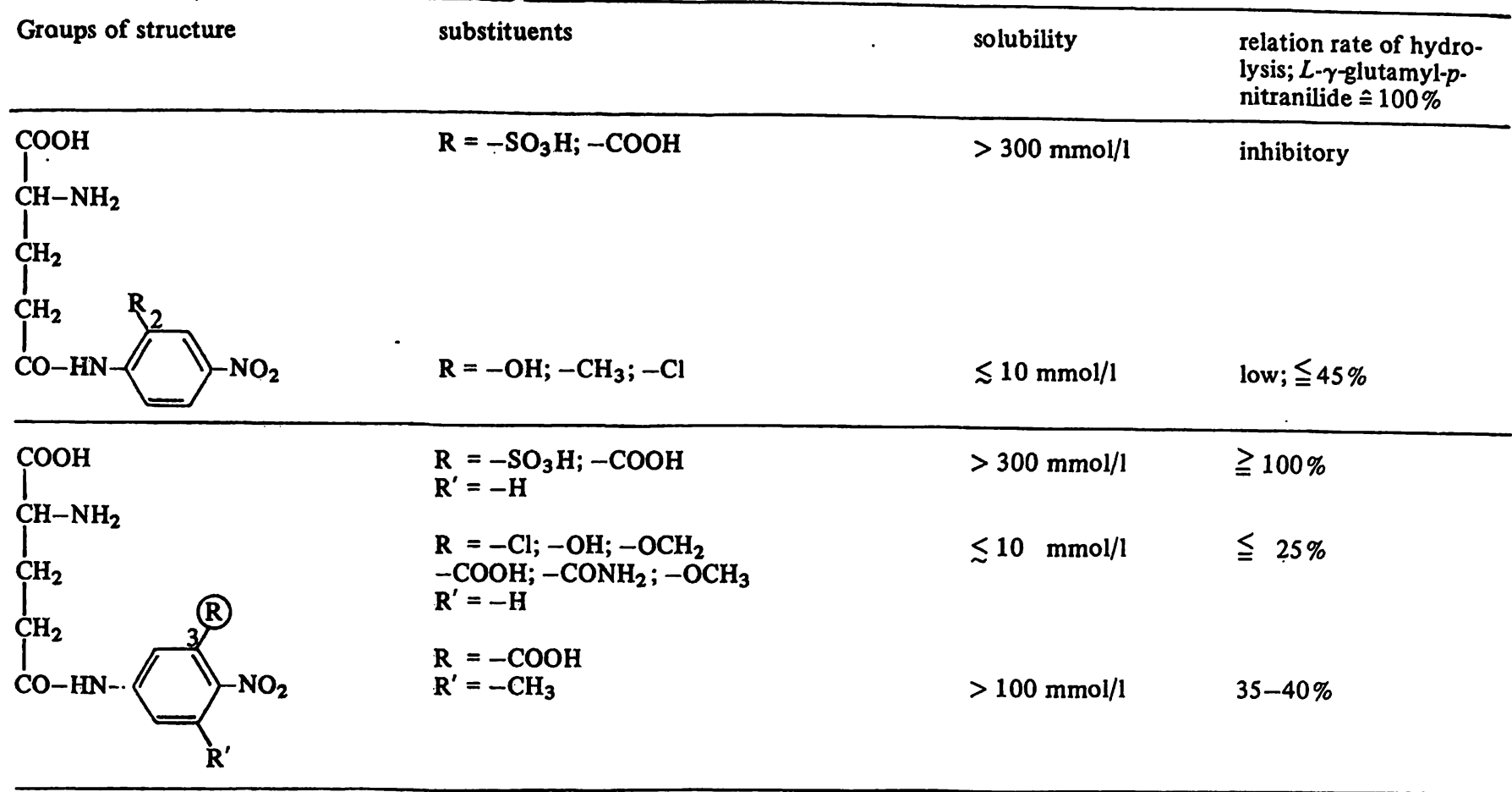

$\int_{\mathrm{C}}^{\mathrm{COOH}} \mathrm{C}-\mathrm{NH}_{2}$

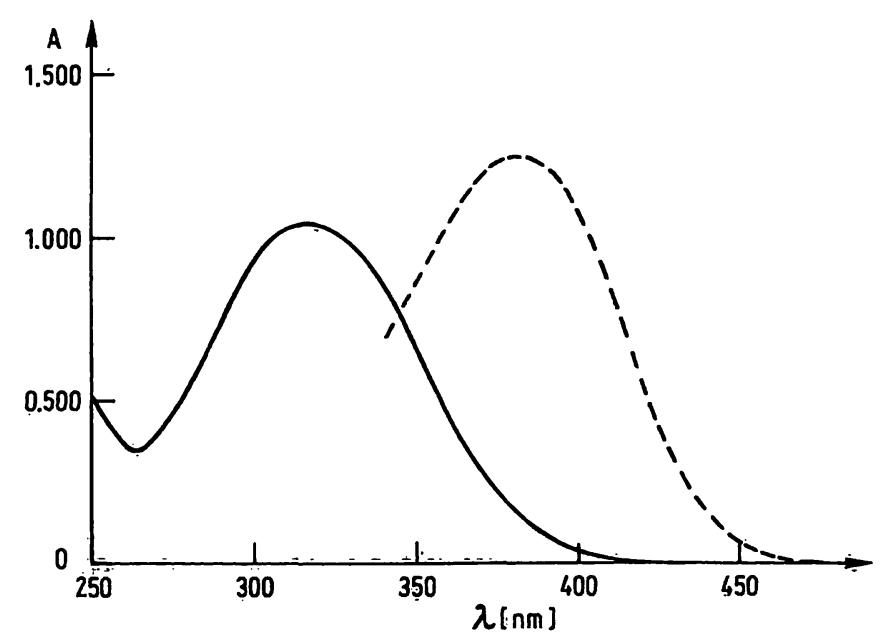

Fig. 1. Absorption spectrum of $L$-r-glutamyl-3-carboxy-4nitranilide in Tris buffer (pH 8.2, $200 \mathrm{mmol} / \mathrm{l})$. For comparison: the absorption spectrum of 2-nitro-5-aminobenzoic acid $(---)$.

tivity: $4.57 \mathrm{~cm}^{2} / \mu \mathrm{mol}$ ) respectively. The absorption pattern of $L-\gamma$-glutamyl-3-carboxy-4-nitranilide is shown in Figure 1.

\section{Optimal condition}

The dependence of $\gamma$-glutamyltransferase on $\mathrm{pH}$ with both substrates was tested in various buffers. The optimal $\mathrm{pH}$ in Tris- $\mathrm{HCl}$ buffer was between 8.1 and 8.3 for $L$ $\gamma$-glutamyl-3-carboxy-4-nitranilide and between 8.2 and 8.4 for $L$ - $\gamma$-glutamyl-3-sulphonic-4-nitranilide (fig. 2). An identical curve was obtained in ammediol-HCl buffer (100 mmol/1), but activities were slightly lower. At $37^{\circ} \mathrm{C}$ the optimal $\mathrm{pH}$ value is nearly the same. Tris- $\mathrm{HCl}$ buffer was taken as the buffer of choice due to its optimal buffering capacity in this $\mathrm{pH}-$ range $\left(\mathrm{pK}_{\mathrm{a}}=8.1\right)$. The influence of the concentration of Tris buffer on enzymic activity is shown in figure 3 . A concentration of 100 $\mathrm{mmol} / \mathrm{l}$ was as a rule used in the other experiments.

The optimal concentration of glycylglycine as acceptor was about $150 \mathrm{mmol} / 1$ both at $25^{\circ} \mathrm{C}$ and $37^{\circ} \mathrm{C}$. Examples are presented in figures 4 and 5 .

The highest activities were measured at substrate concentrations between 4 and $8 \mathrm{mmol} / \mathrm{l}$. Higher substrate concentrations caused inhibition of activity (fig. 5). Optimal activities can therefore not be measured at substrate concentrations which equal $40 \times K_{\mathrm{m}}$. The 


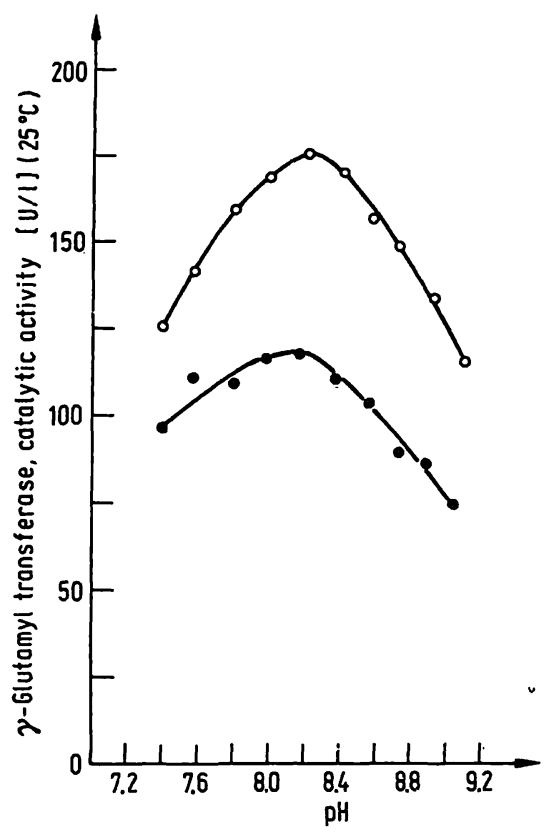

Fig. 2. Dependence of $\gamma$-glutamyltransferase activity upon $\mathrm{pH}$ using $L-\gamma$-glutamyl-3-sulphonic-4-nitranilide $(0-0)$ or $L$ - $\gamma$-glutamyl-3-carboxy-4-nitranilide $(\bullet-)$ in concentrations of $8 \mathrm{mmol} / \mathrm{l}$.

Measurements in Tris $\mathrm{HCl}$ buffer $(100 \mathrm{mmol} / \mathrm{l})$ and Glycylgly cine $(100 \mathrm{mmol} / \mathrm{l})$.

All these experiments were carried out with the same serum.

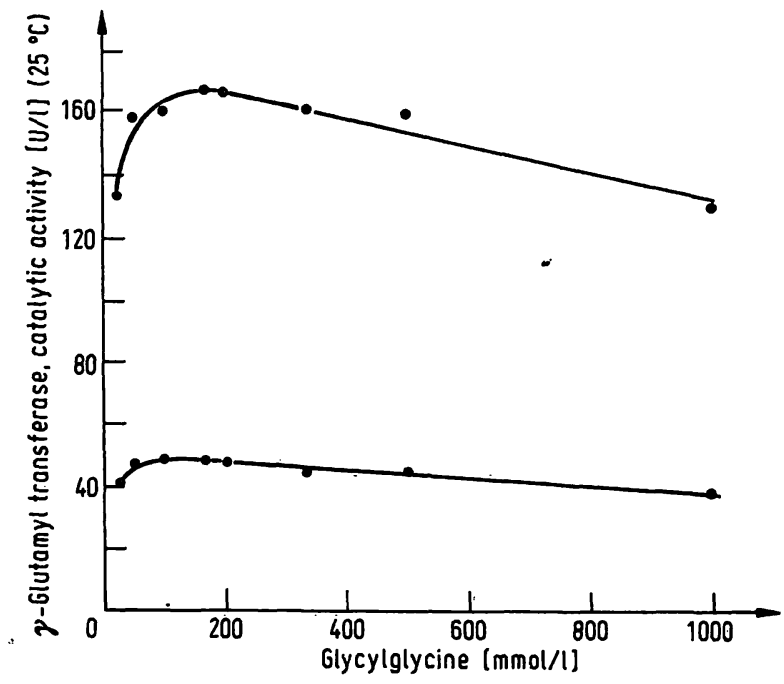

Fig. 4. Enzyme activity with $L$ - $\gamma$-glutamyl-3-carboxy-4-nitranilide $(8 \mathrm{mmol} / \mathrm{l})$ as a function of concentration of glycylglycine in Tris buffer ( $\mathrm{pH} 8.2,100 \mathrm{mmol} / \mathrm{l})$. These experiments were carried out with two different sera.

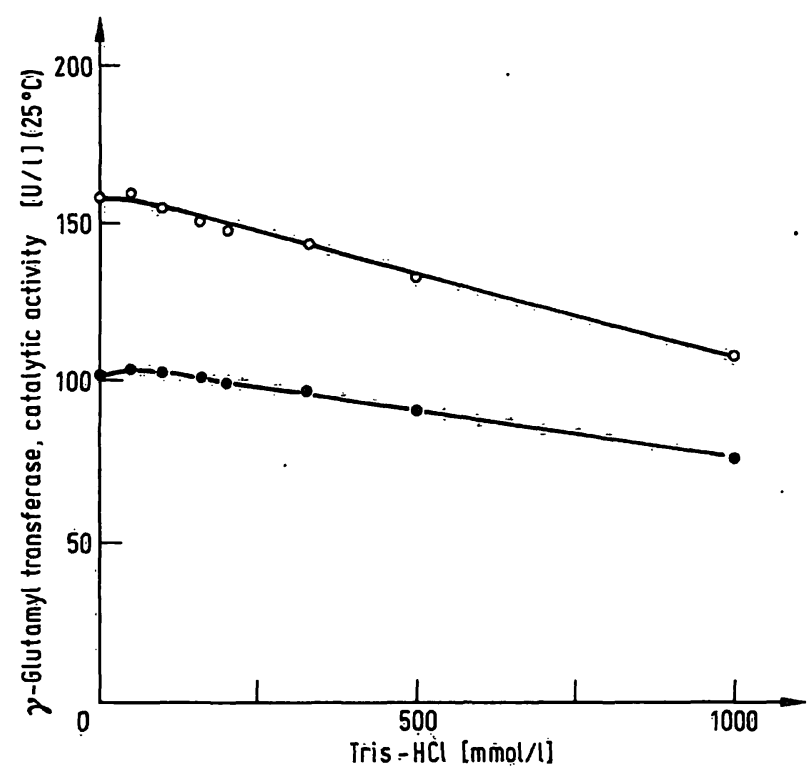

Fig. 3. Enzyme activity as a function of concentration of Tris $\mathrm{HCl}$ buffer (pH 8.2). Substrate: $L$ - $\gamma$-glutamyl-3-sulphonic4-nitranilide (0-0, $6 \mathrm{mmol} / \mathrm{l}$ ) or $L$ - $\gamma$-glutamyl-3-carboxy4-nitranilide $(\longrightarrow, 6 \mathrm{mmol} / \mathrm{l})$. Incubation medium contained glycylglycine $(100 \mathrm{mmol} / \mathrm{l})$. All these experiments were carried out with the same serum.

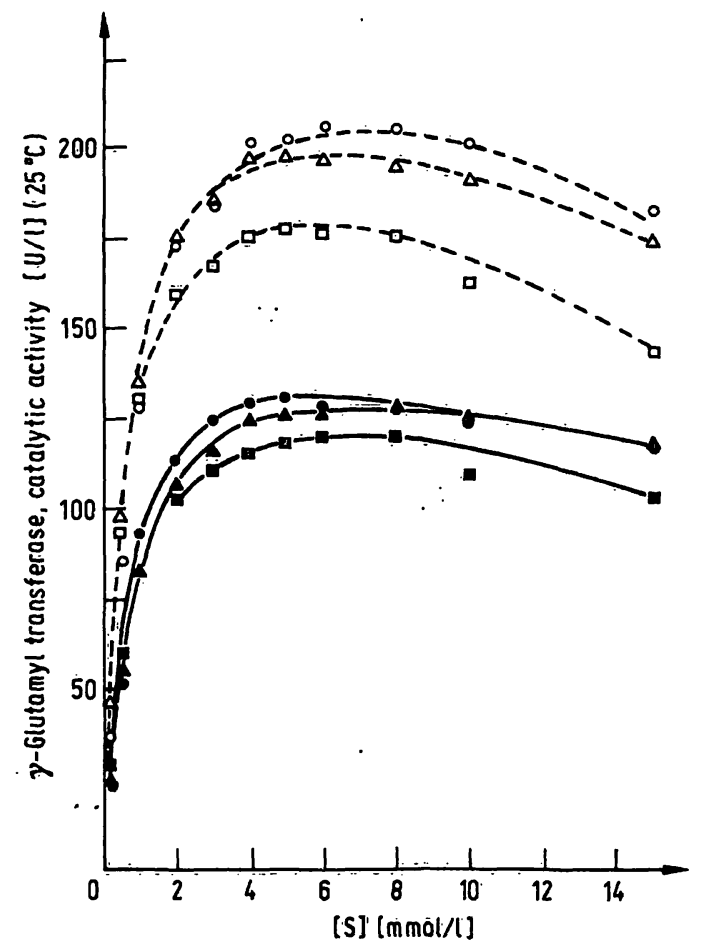

Fig. 5. Effect of substrate concentration on $\gamma$-glutamyltransferase activity. Open signs refer to $L$ - $\gamma$-glutamyl-3-sulphonic-4nitranilide, filled signs to $L$ - $\gamma$-glutamyl-3-carboxy-4-nitranilide in the presence of glycylglycine, $50 \mathrm{mmol} / \mathrm{l}$ (rectangles), $100 \mathrm{mmol} / \mathrm{l}$ (triangles) and $150 \mathrm{mmol} / \mathrm{i}$ (circles). All these experiments were carried out with the same serum. 
selected optimal conditions were: $\mathrm{Tris}-\mathrm{HCl}$ buffer $100 \mathrm{mmol} / 1$ (pH 8.2 for $L$ - $\gamma$-glutamyl-3-carboxy-4nitranilide and $\mathrm{pH} 8.3$ for $L \cdot \gamma$-glutamyl-3-sulphonic-4nitranilide), substrate $6 \mathrm{mmol} / \mathrm{l}$ and glycylglycine $150 \mathrm{mmol} / \mathrm{l}$.

\section{Evaluation of the method}

\section{Relationship between absorbance and enzyme level}

Serum activities with $L-\gamma$-glutamyl-3-carboxy-4-nitranilide and $L$ - $\gamma$-glutamyl-3-sulphonic-4-nitranilide are directly proportional to the amount of serum (fig. 6). Heatinactivated serum as well as physiological saline were used as diluents in the experiments. An identical result was obtained at an incubation temperature of $37^{\circ} \mathrm{C}$.

\section{Influence of temperature}

The temperature dependence of serum activity with $L$ - $\gamma$-glutamyl-3-carboxy-4-nitranilide and $L$ - $\gamma$-glutamyl3-sulphonic-4-nitranilide was studied in the range $25-41^{\circ} \mathrm{C}$. A linear relationship between logarithms of activity and reciprocals of absolute temperature was found to exist between $25^{\circ} \mathrm{C}$ and $30^{\circ} \mathrm{C}$. Above $30^{\circ} \mathrm{C}$, deviation from linearity was more marked in the case of $L$ - $\gamma$-glutamyl-3-carboxy-4-nitranilide (fig. 7 ).

\section{Comparative studies}

In twenty-nine sera, $\gamma$-glutamyltransferase was measured according to Szasz (6) as well as with the substrates

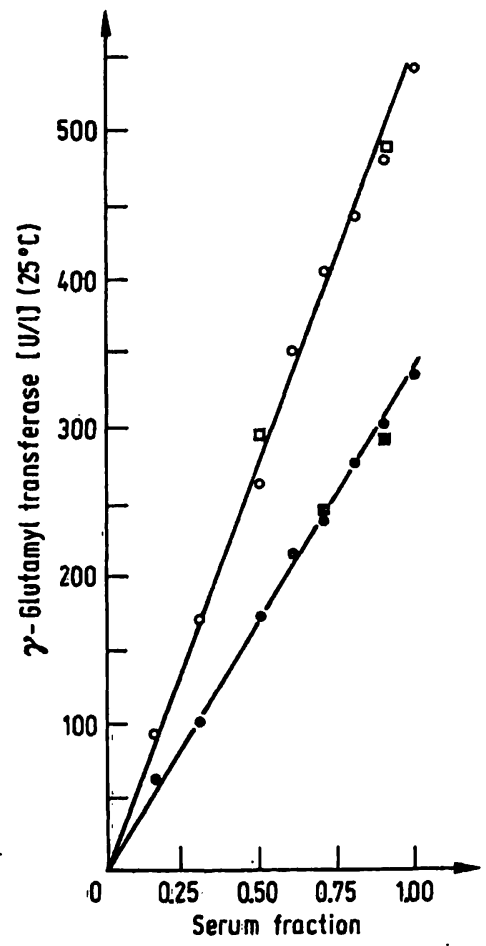

Fig. 6. Relation of enzyme concentration to $\gamma$-glutamyltransferase activity as measured with $L$ - $\gamma$-glutamyl-3-sulphonic4-nitranilide $(0-0)$ or $L$-r-glutamyl-3-carboxy-4-nitranilide $(\bullet-)$ under optimal conditions. Dilutions were made up with heat inactivated serum (circles) or physiological saline (rectangles).
$L$ - $\gamma$-glutamyl-3-carboxy-4-nitranilide and $L$ - $\gamma$-glutamyl-3sulphonic-4-nitranilide (under optimal conditions). The results shown in figure 8 demonstrate that the activity obtained with $L$ - $\gamma$-glutamyl-3-sulphonic-4-nitranilide was 1.89 times and that obtained with $L$ - $\gamma$-glutamyl-3-carboxy4-nitranilide was 1.22 times that obtained according to Szasz.

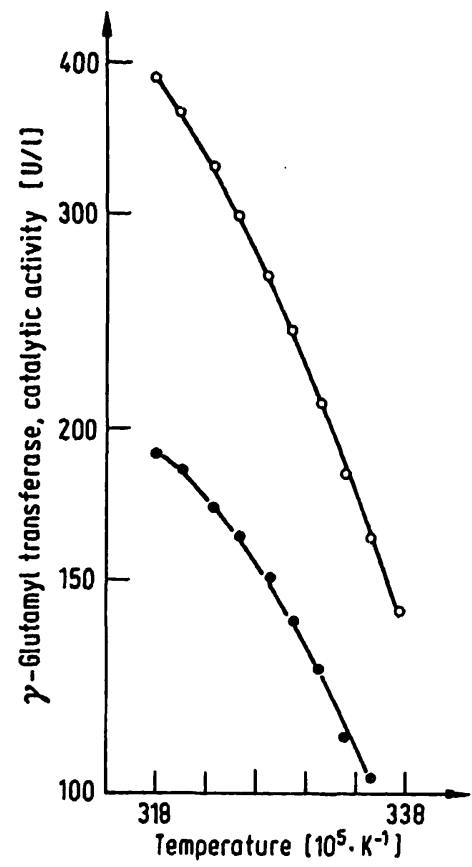

Fig. 7. Dependence of $\gamma$-glutamyltransferase activity upon temperature of incubation; plotted according to Arrhenius. Substrate: $L-\gamma-g l u t a m y l-3-s u l p h o n i c-4-n i t r a n i l i d e$ $(\circ \longrightarrow)$ or $L$ - $\gamma$-glutamyl-3-carboxy-4-nitranilide $(\bullet \longrightarrow)$.

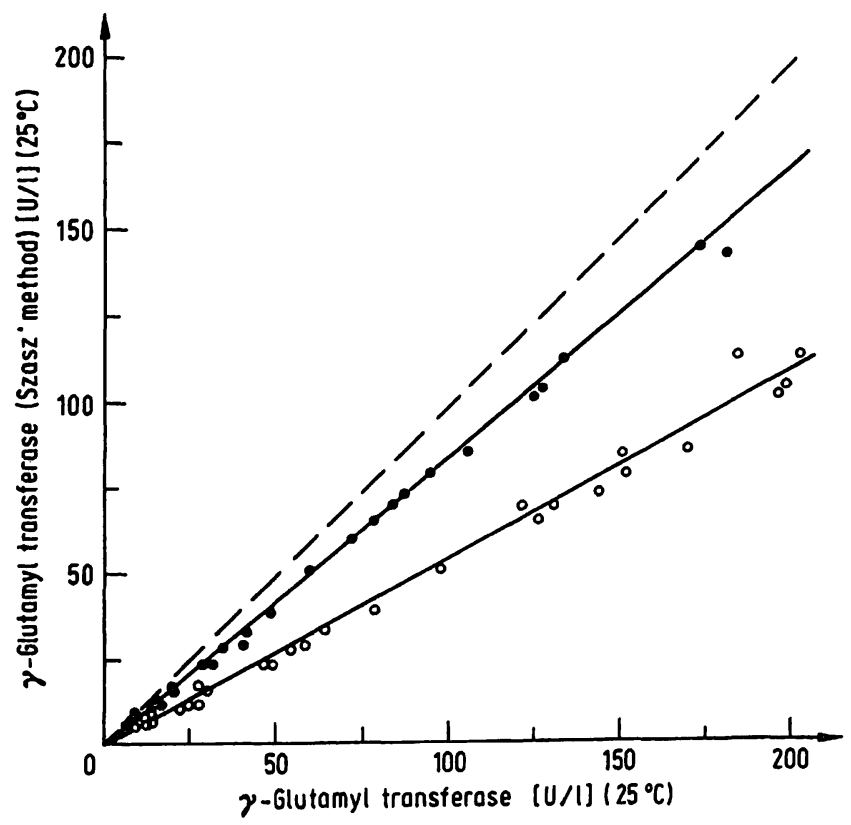

Fig. 8. Comparison of $\gamma$-glutamyltransferase activities measured with $L$ - $\gamma$-glutamyl-3-carboxy-4-nitranilide $(\bullet-)$ or $L$ - $\gamma$-glutamyl-3-sulphonic-4-nitranilide $(0-0)$ under optimal conditions with those obtained with the method according to Szasz (plotted on the ordinate) using $L-\gamma$ glutamyl-p-nitranilide.

$Y(L-\gamma$-glutamyl-p-nitranilide $)=0.82138 \times(L-\gamma$-glutamyl3-carboxy-4-nitranilide) $-0.62195(r=0.99929)$.

$\mathrm{Y}(L$ - $\gamma$-glutamyl-p-nitranilide $)=0.52868 \mathrm{X}(L-\gamma$-glutamyl3-sulphonic-4-nitranilide) $-0.52121(\mathrm{r}=0.99688)$. 


\section{Accuracy}

The coefficients of variation (C.V.) of $\boldsymbol{\gamma}$-glutamyltransferase as measured with $L$ - $\gamma$-glutamyl-3-carboxy-4-

nitranilide were $4.2 \%$ for the range $20-40 U / 1(n=50)$ and $1.0 \%$ for the range $100-140 \mathrm{U} / 1(\mathrm{n}=40)$. They were calculated from duplicates of assays, performed during a period of about six months, by the formula

C.V. $=\frac{100 S}{\bar{x}}$, where $S=\sqrt{\frac{\Sigma d^{2}}{N}}$

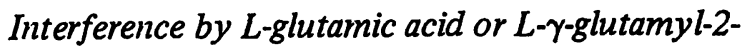 carboxy-4-nitranilide}

Experiments with $L$-glutamic acid, which reportedly increases $\gamma$-glutamyltransferase (21), have been described elsewhere in detail (22). Briefly, no increase in activity was found when $L$-glutamic acid was incorporated in the test media at concentrations of $10-5000 \mu \mathrm{mol} / 1$.

$\boldsymbol{\gamma}$-Glutamyltransferase is inhibited competitively by $L-\gamma$ glutamyl-2-carboxy-4-nitranilide. The activity found at a concentration equimolar to $L$ - $\gamma$-glutamyl-3-carboxy-4nitranilide (i. e. $6 \mathrm{mmol} / \mathrm{l}$ ) was about $20 \%$ lower.

\section{Interference by glycine}

In determining the optimal glycylglycine concentration with various preparations, one preparation showed a marked decrease in $\gamma$-glutamyltransferase at higher concentrations than that indicated in figure 4. Gaschromatographic analysis revealed pollution of this preparation with glycine. The effect of glycine was consequently studied and the results presented in figure 9 show that,

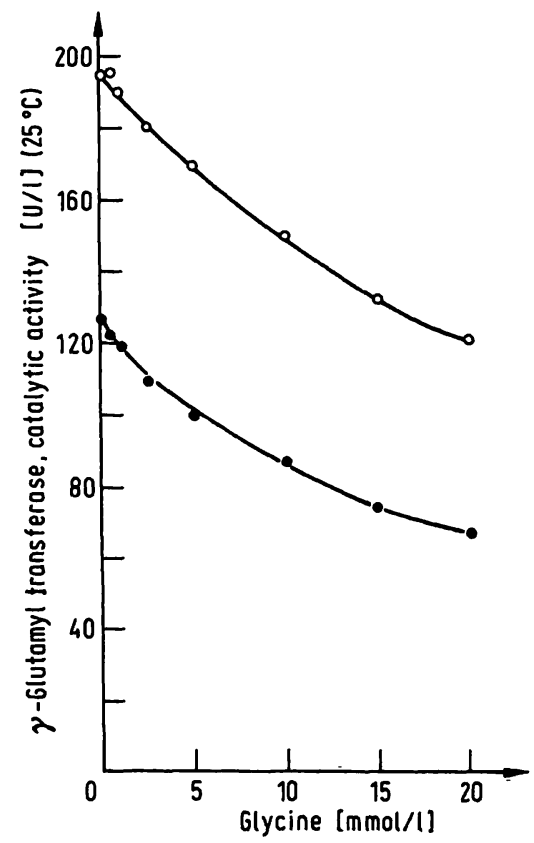

Fig. 9. Effect of glycine on $\gamma$-glutamyltransferase activity measured with $L-\gamma$-glutamyl-3-carboxy-4-nitranilide $(\bullet-)$ or $L$ - $\gamma$-glutamyl-3-sulphonic-4-nitranilide $(0-0)$ under optimal conditions. in the presence of glycylglycine, glycine has an inhibitory effect. An identical curve was obtained at $37^{\circ} \mathrm{C}$.

\section{Interference by hemolysis}

A haemoglobin concentration lower than $3 \mathrm{~g} / \mathrm{l}(0.19$ $\mathrm{mmol} / \mathrm{l}$ ) serum does not interfere with the reaction. Higher haemoglobin concentrations result in a decreased enzymic activity, the decrease being about $20 \%$ at $5 \mathrm{~g} / \mathrm{l}$ (0.31 mmol/l) serum.

\section{Concluding Remarks}

The method proposed has the advantages of the method in current use, i. e. the Szasz method (6) and applies a new substrate characterized by high solubility and an acceptable molar absorptivity of the cleavage product. The method is therefore simpler, because various more or less complicated attempts to prepare substrate solutions at optimal concentration, as with $L-\gamma$-glutamyl$p$-nitranilide, are not required. The data in figure 8 warrant the conclusion, moreover, that the clinical significance of $\boldsymbol{\gamma}$-glutamyl-transferase, as established by various authors using $L$ - $\gamma$-glutamyl-p-nitranilide (7-16), can be maintained when the proposed method is applied. We prefer $L$ - $\gamma$-glutamyl-3-carboxy-4-nitranilide for the following reason. The fact that higher activities are measured with $L$ - $\gamma$-glutamyl-3-sulphonic-4-nitranilide than with $L$ - $\gamma$-glutamyl-3-carboxy-4-nitranilide is of no advantage because the absorption coefficient of the coloured cleavage product of $L$ - $\gamma$-glutamyl-3-sulphonic4-nitranilide is substantially lower.

To give an example: table 2 presents the activities and corresponding $\Delta \mathrm{A} / \mathrm{min}$ values obtained with the substrates $L$ - $\gamma$-glutamyl-3-carboxy-4-nitranilide and $L$ - $\gamma$ glutamyl-3-sulphonic-4-nitranilide in a serum which according to $S z a s z$ had a $\gamma$-glutamyltransferase of $100 \mathrm{U} / \mathrm{l}$. All $\Delta \mathrm{A} / \mathrm{min}$ values in table 2 refer to an identical amount of serum $(0.2 \mathrm{ml})$, added to an identical amount of buffered substrate $(3 \mathrm{ml})$. The data show that the $\Delta \mathrm{A} / \mathrm{min}$ with which the $\gamma$-glutamyl-transferase is measured in the borderline region between normal and pathological is more favourable with $L$ - $\gamma$-glutamyl-3carboxy-4-nitranilide than with $L-\gamma$-glutamyl-3-sulphonic4nitranilide.

Tab. 2. Comparison of activities and corresponding initial changes of absorbance $(1.0 \mathrm{~cm}$ lightpath).

\begin{tabular}{ll}
\hline & $\begin{array}{l}\text { A } 405 \mathrm{~nm} / \\
\left.\text { min }^{1}\right)\end{array}$ \\
\hline $100 \mathrm{U} / 1$ according to Szasz (6) method & 0.062 \\
$122 \mathrm{U} / 1$ with $L$ - $\gamma$-glutamyl-3-carboxy-4-nitranilide $\left.{ }^{2}\right)$ & 0.071 \\
$189 \mathrm{U} / 1$ with $L$ - $\gamma$-glutamyl-3-sulphonic-4-nitranilide ${ }^{2}$ ) & 0.059 \\
\hline
\end{tabular}

1) $3 \mathrm{ml}$ buffer substrate

$0.2 \mathrm{ml}$ serum

2) measured under optimal conditions 
We therefore propose the procedure using $L$ - $\gamma$-glutamyl3-carboxy-4-nitranilide as the method of choice under the conditions described in Materials and Methods. Glycine-free glycylglycine should be used.

The advantages described above make it possible to adapt the assay to any kind of automation without changing the conditions.

\section{References}

1. Hanes, C. S., Hird, F. J. R. \& Isherwood, F. A. (1952), Biochem. J. 51, 25-35.

2. Szewczuk, A. \& Orlowski, M. (1960), Clin. Chim. Acta, $5,680-688$.

3. Goldbarg, J. A., Friedman, O. M., Pineda, E. P., Smith, E. E., Chattereji, R., Stein, E. H. \& Rutenburg, A. M. (1960), Arch. Biochem. Biophys. 91, 61-70.

4. Orlowski, M. \& Szewczuk, A. (1962), Clin. Chim. Acta, 7, 755-762.

5. Orlowski, M. (1965), Arch. Immunol. Therap. Exper., 13, 538-547.

6. Szasz, G. (1969), Clin. Chem., 15, 124-136.

7. Hedworth, R. B., Whitfield, J. B. \& Richardson, R. W. (1967), Brit. Heart J., 29, 432-438.

8. Cohen, M. I. \& McNamara, H. (1969), J. Pediatrics, 75, 838-842.

9. Szasz, G., Rosenthal, P. \& Fritzsche, W. (1969), Dtsch. Med. Wochenschr. 38, 1911-1917.

10. Ravens, K. G., Gudbjarnason, S., Cowan, Ch. M. \& Bing, R. J. (1969), Circulation, 39, 693-700.

11. Lehmann, D., Prentice, M. \& Rosalki, S. B. (1970), Ann. Clin. Biochem. 7, 148-151.

\section{Acknowledgement}

This study would not have been possible without the cooperation of Dr. $W$. Gruber, Tutzing, Germany, whose continuing support and stimulating interest is gratefully acknowledged.

The authors are also indebted to Prof. G. Szasz, Gießen, Germany, for valuable advices.

Skilfull technical assistance was given by miss $R$. E. van Pesch.

12. Jacobs, W. L. W. (1972), Clin. Chim. Acta, 38, 419-434

13. Betro, M. G., Oon, R.C.S. \& Edwards, J. B. (1973), Am. J. Clin. Pathol. 60, 679-683.

14. Korsten, C. B., Persijn, J. P. \& Van der Slik, W. (1974), this J. 12, 116-120.

15. Schmidt, E. \& Schmidt, F. W. (1973), Dtsch.Med. Wochenschr. 98, 1572-1578.

16. Rosalki, S. B. \& Rau, D. (1972), Clin. Chim. Acta, 39, 41-47.

17. Szasz, G., Weimann, G., Stähler, F., Wahlefeld, A. W. \& Persijn, J. P. (1974), this J. 12, 228.

18. Bernt, E., Stähler, F. \& Persijn, J. P. (1975), Clin. Chem. $21,996$.

19. Persijn, J. P., Van der Slik, W., Timmer, C. J. \& Riethorst, A. (1970), Clin. Chim. Acta 30, 377-386.

20. Henry, R. J. \& Dryer, R. L. (1963) in Standard Methods of Clinical Chemistry (Seligson, D. Ed.) vol. 4, p. 216, Academic Press, N. York.

21. Bondar, R. J. L. \& Moss, G. A. (1974), Clin. Chem., 20, 317-319.

22. Gerhardt, W., Persijn, J. P. \& Rosalki, S. B. (1975), Clin. Chem. 21, 1515-1517.
Dr. J. P. Persijn

Antoni van Leeuwenhoek Ziekenhuis Plesmanlaan 121

Amsterdam 
$$
\text { . }
$$ 